\title{
p65 down-regulates DEPTOR expression in response to LPS stimulation in hepatocytes
}

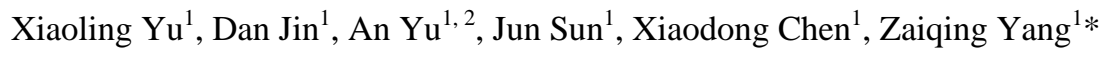

${ }^{1}$ Key Laboratory of Agricultural Animal Genetics, Breeding and Reproduction of Ministry of Education, College of Life Science and Technology, Huazhong Agricultural University, Wuhan 430070, China

${ }^{2}$ Huffington Center on Aging, Baylor College of Medicine, Houston, Texas 77030, USA

* Corresponding author, address: College of Life Science and Technology, Huazhong Agricultural University, Wuhan 430070, China. Tel: +86 27 87282669; fax: +86 2787287376.

E-mail addresses: yuy07@webmail.hzau.edu.cn (Xiaoling Yu), yangzq@mail.hzau.edu.cn (Zaiqing Yang)

\begin{abstract}
DEPTOR, a novel endogenous inhibitor of mTOR, plays an important role in regulating the inflammatory response in vascular endothelial cells (ECs) and in mouse skeletal muscle. However, the regulatory mechanism of DEPTOR transcription and its effects on liver inflammation are unknown presently. Here we reported the role of DEPTOR in regulating inflammatory response in mouse liver-derived Hepa1-6 cells and in a mouse model with LPSinduced hepatic inflammation. The results revealed that DEPTOR over-expression in Hepa1-6 liver cells increased the mRNA levels of the pro-inflammatory cytokines interleukin-6 (IL- 6$)$ and monocyte chemotactic protein-1 (MCP-1). Contrasting results were observed in Hepa1-6 cells with DEPTOR interference. Treatment Hepa1-6 cells with rapamycin, a specific inhibitor of mTORC1, increased MCP-1 mRNA, but have no significant effect on $I L-6$ mRNA. DEPTOR expression was down-regulated in Hepa1-6 cells with the treatment of inflammatory stimuli LPS or the over-expression of $\mathrm{p} 65 / \mathrm{NF}-\kappa \mathrm{B}$, a key inflammatory transcription factor. $\mathrm{NF}-\kappa \mathrm{B}$ antagonist
\end{abstract}


(PDTC) and inhibitor $(\mathrm{I} \kappa \mathrm{B} \alpha)$ blocked the effect of LPS on DEPTOR expression. The study in vivo showed that DEPTOR mRNA and protein were significantly reduced in a mouse model with LPS-induced hepatic inflammation, which was accompanied by a concurrent activation of the mTOR signaling pathway. Further, the transcriptional regulation of DEPTOR was explored, which revealed that $D E P T O R$ promoter activity was significantly down-regulated by NF- $\kappa \mathrm{B}$. The progressive deletions and mutations demonstrated that the NF- $\kappa \mathrm{B}$ binding motif situated at $-145 /-$ 127 region is an essential component required for the DEPTOR promoter activity. Chromatin immunoprecipitation(ChIP) assays determined that p65 can directly interact with the DEPTOR promoter DNA. Those results indicate DEPTOR regulates liver inflammation at least partially via mTORC1 pathway, and is down-regulatd by LPS through p65.

Keywords: mTOR, NF- $\mathrm{B}$, promoter, transcription, inflammation

\author{
Abbreviations \\ DEPTOR, DEP domain containing MTOR-interacting protein; ECs, vascular endothelial cells; \\ NF- $\kappa \mathrm{B}$, nuclear factor for kappa B; IL-6, cytokine interleukin-6; MCP-1, monocyte chemotactic \\ protein-1; LPS, lipopolysaccharide
}

\title{
1. Introduction
}

Approximately $80 \%$ of the hepatic blood supply is from the gastrointestinal tract via the portal vein, so the liver is continually exposed to dietary and microbial antigens such as lipopolysaccharide (LPS) which stimulates Toll-like receptors (TLR), and causes inflammatory 
responses(Nemeth et al., 2009; Miyake and Yamamoto, 2013). The liver is comprised of 60-80\% hepatocytes with the rest of the cell population consisting of endothelial cells, Kupffer cells, lymphocytes, biliary cells and stellate cells(Racanelli and Rehermann, 2006). Hepatocytes can directly clear LPS(Treon et al., 1993; Mimura et al., 1995; Scott and Billiar, 2008), indicating their important role in inflammatory responses.

Inflammation, a common and important pathological process, is associated with homeostasis(Kotas and Medzhitov, 2015), metabolic diseases(Hotamisligil, 2006; Baker et al., 2011), cancer(Lisa M. Coussens, 2002; Mantovani et al., 2008; Grivennikov et al., 2010) and other diseases. Nuclear factor for kappa B (NF- $\kappa \mathrm{B})$, a heterodimer with p50/p52 and p65 subunits, is critical for inflammatory regulation(Baker et al., 2011). The mammalian target of rapamycin (mTOR), an evolutionarily conserved serine/threonine protein kinase, forms two distinct multiprotein complexes named mTORC1 and mTORC2 that share the mTOR, mLST8/G $\beta L$, and DEPTOR proteins, and differ with raptor and PRAS40 in mTORC1 and rictor, mSin1 in mTORC2(Laplante and Sabatini, 2012). mTORC1 directly phosphorylates the translational regulators eukaryotic translation initiation factor 4E (elF4E)-binding protein 1 (4EBP1) and S6 kinase 1 to promote protein synthesis through different pathway, and directly phosphorylates and suppresses ULK/Atg13/FIP200 (unc-51-like kinase 1/mammalian autophagy-related gene 13/focal adhesion kinase family-interactiong protein of $200 \mathrm{kDa}$ ) to inhibit autophagy. mTORC2 controls Akt, serum- and glucocorticoid-induced protein kinase 1 (SGK1), and protein kinase C- $\alpha$ (PKC- $\alpha)$ to regulate cell survival/metabolism and cytoskeletal organization. mTORC1 is sensitive to rapamycin, while mTORC2 is insensitive to rapamycin. The effects of rapamycin on mTORC2 signaling are much more complex as long term treatment in different types of cells(Sarbassov et al., 2006; Laplante and Sabatini, 2012). Recently, studies 
indicated that mTORC1 can control NF- $\mathrm{BB}$ activity (Dan et al., 2008; Fielhaber et al., 2012; Gao et al., 2015; Yin et al., 2015), as well as can be activated by pro-inflammatory cytokines(Lee et al., 2007).These evidences suggest that mTORC1 is involved in inflammatory responses.

DEPTOR interacts with mTOR and inhibits mTORC1/2 pathways(Peterson et al., 2009). It plays an important role in proliferation(Zhang et al., 2013b), apoptosis(Zhang et al., 2013a), regulation pluripotency of embryonic stem cells(Agrawal et al., 2014), and adipogenesis(Laplante et al., 2012). Recent studies reveal that DEPTOR is a critical upstream regulator of vascular endothelial cells (ECs) activation and is involved in the inflammatory response of ECs(Bruneau et al., 2013). DEPTOR is also a target of pro-inflammatory cytokine $T N F-\alpha$ and participates in skeletal muscle inflammation in obese mice(Meng et al., 2014). These data demonstrated the roles of DEPTOR in ECs and skeletal muscle inflammation through its interaction with mTOR, however, it is unclear presently whether DEPTOR is involved in regulating hepatic inflammatory responses.

In the present study, our results suggest that DEPTOR over-expression significantly upregulated the mRNA levels of the pro-inflammatory cytokines interleukin-6 (IL-6) and monocyte chemotactic protein-1 (MCP-1) in Hepa1-6 liver cells, while its own expression was obviously down-regulated in Hepa1-6 cells treated with inflammatory stimuli LPS or p65/NF- $\mathrm{BB}$ overexpression. DEPTOR expression was also significantly inhibited in a mouse model with LPSinduced liver inflammation, which was accompanied by a concurrent activation of mTOR signaling pathway. mTORC1 inhibitor rapamycin increased $M C P-1 \mathrm{mRNA}$, but have no significant effect on $I L-6$ mRNA. The progressive deletions and mutations demonstrated that the $\mathrm{NF}-\kappa \mathrm{B}$ binding motif situated at $-145 /-127$ region is an essential component required for the DEPTOR promoter activity. Chromatin immunoprecipitation(ChIP) assays determined that p65 
can directly interact with the DEPTOR promoter DNA. Our data together suggested that DEPTOR, transcriptionally regulated by $\mathrm{p} 65 / \mathrm{NF}-\kappa \mathrm{B}$, plays an important role in regulating liver inflammatory response at least partially via mTORC1 signaling pathway.

\section{Materials and methods}

\subsection{Animal experiments}

C57BL/6 mice (7 weeks-of-age) were purchased from the animal experiment center of Wuhan University. Mice were housed in individual plastic cages under a12/12 h light-dark cycle with free access to water and food at room temperature. They acclimated for one week before the study, after which they were treated with or without LPS (L2880, Sigma, 10mg/kg, ip) for $12 \mathrm{~h}$, and then sacrificed. Liver portions were removed and fixed with $4 \%$ paraformaldehyde solution. Some liver tissue and muscle and visceral fat were placed in liquid nitrogen and stored in $-70{ }^{\circ} \mathrm{C}$. All procedures were in accordance with the Hubei Province Committee on Laboratory Animal Care.

\subsection{Plasmids}

The complete coding sequences of murine DEPTOR were obtained from the NCBI gene database. The gene fragment was amplified by PCR and inserted into pcDNA3.1 vector. The target sequences (CAAGGAAGACATTCACGAT) for DEPTOR interference from the published literature [17] were ligated to the pSilencer4.1 CMV vector. Murine DEPTOR 
promoter vectors were constructed according to bioinformatic analysis. A series of murine DEPTOR promoter fragments were amplified by PCR and inserted into the pGL3-basic vector. Primer sequences are shown in Table 1.

\subsection{Cell culture}

Hepa1-6 cells were obtained from the Cell Bank of the Chinese Academy of Science, and cultured in Dulbecco's modified Eagle's medium (DMEM, Hyclone) supplemented with 10\% fetal bovine serum (FBS, Sijiqing) under 5\% CO2 and $37^{\circ} \mathrm{C}$. HEK293 cells were purchased from the Wuhan Cell Bank of Wuhan University, and cultured as Hepa1-6 cells.

\subsection{Cell transient transfection}

Cells were cultured on 12-well culture plates to $70-80 \%$ confluency in 10\% FBS/DMEM at the time of transfection. Plasmids $(2 \mu \mathrm{g})$ were transfected into cells with $2 \mu$ l Lipofectamine 2000 reagent (Invitrogen) in serum-free medium Opti-MEM (Gibco). The medium was replaced

with $10 \%$ FBS/DMEM after 6 h. pEGFP vector was used to monitor the transfection efficiency. In over-expression experiments, cells were collected $24 \mathrm{~h}$ later. In shRNA knockdown experiments, cells were collected $48 \mathrm{~h}$ later. For transfection with LPS, LPS was added to the medium $12 \mathrm{~h}$ prior to cell collection.

\subsection{Nuclear acid isolation and quantitative real time PCR (qRT-PCR)}


Total RNA was extracted from tissue or cells using TRIzol reagent (Takara) according to the manufacturer's protocol. RNA $(2-3 \mu \mathrm{g})$ was reverse transcribed into cDNA in $30 \mu \mathrm{L}$ reaction solution using a Reverse Transcription Kit (Takara). qRT-PCR was performed in a $20 \mu \mathrm{L}$ reaction volume containing appropriate primers (Table 2) using SYBR Green PCR Mix (Bio-Rad) with a CFX96 ${ }^{\mathrm{TM}}$ real time PCR system. Murine $\beta$-actin was used as an internal reference to normalize relative gene expression. qRT-PCR conditions were $95^{\circ} \mathrm{C}$ for $3 \mathrm{~min}$, followed by 45 cycles of $95{ }^{\circ} \mathrm{C}$ for $12 \mathrm{sec}, 60{ }^{\circ} \mathrm{C}$ for $12 \mathrm{sec}$, and $72{ }^{\circ} \mathrm{C}$ for $12 \mathrm{sec}$.

\subsection{Western Blotting}

Cells collected and centrifuged in PBS or tissue ground with liquid nitrogen were lysed in RIPA lysis buffer P0013 (Beyotime) with PMSF. Before lysates were added to 5X native loading buffer, protein concentrations were measured with a BCA kit (Invitrogen). Samples were boiled

at $100{ }^{\circ} \mathrm{C}$ for $15 \mathrm{~min}$, and subjected to SDS-PAGE, and then transferred to PVDF membranes. Membranes were blocked with 1XTBST buffer (20 mM Tris, PH 7.5, $150 \mathrm{mM} \mathrm{NaCl,} 50 \mathrm{mM}$ $\mathrm{KCl}$, and $0.5 \%$ Tween-20) containing 5\% non-fat dry milk (R\&D) on an orbital shaker for $1 \mathrm{~h}$ or overnight at $4{ }^{\circ} \mathrm{C}$. Individual protein was incubated with primary antibody at the appropriate dilution with constant rocking for $1 \mathrm{~h}$ or overnight at $4{ }^{\circ} \mathrm{C}$. HRP-conjugated secondary antibody (Dingguo) was incubated with the membrane (1: 5000) for $1 \mathrm{~h}$ on an orbital shaker at room temperature. Signals were measured with an ECL chemiluminescence detection system (Beyotime). The following antibodies were used for Western blot: p-Akt (S473, \#4060, Cell Signaling Technology), p-S6K (T389, \#9205, Cell Signaling Technology), Akt (bs-6951R, 
Bioss), S6K (14485-1-AP, Proteintech), DEPTOR (20985-1-AP, Proteintech), p65 (sc-8008, Santa Cruz Biotechnology), $\beta$-actin(sc-81178, Santa Cruz Biotechnology).

\subsection{Luciferase reporter assays}

Cells were lysed and assayed for promoter activity with a dual-luciferase reporter assay kit (Promega) after $24 \mathrm{~h}$ of transfection. Transfection efficiency was normalized by co-transfection with Renilla luciferase reporter plasmid.

\subsection{Chromatin immunoprecipitation (ChIP) assays}

Hepa1-6 cells were cultivated in a 10-cm culture dishes to $90 \%$ confluence and then treated with or without LPS $(1 \mu \mathrm{g} / \mathrm{ml})$ for $12 \mathrm{~h}$. Next, ChIP assays were performed using a ChIP assay kit (Millipore) according to the manufacturer's protocol. Finally, three pairs of primers (Table 1) were prepared to amplify regions (-2303/-2289, -1780/-1771, -145/-127). IкB $\alpha$ was used as a positive control, and its primers were obtained from the literature(Doig et al., 2014). ChIP-qPCR data was normalized with a fold enrichment method.

\subsection{ELISA}

ELISA was performed according to TNF $\alpha$ ELISA Kit (CSB-E04741m, Cusabio) or MCP-1 ELISA Kit (CSB-E07430m, Cusabio)protocols. A microplate reader was used to measure absorbance at 450nm and data were analyzed with Curve Expert 1.3 software. 


\subsection{H\&E straining}

Liver tissues were fixed with $4 \%$ paraformaldehyde solution for at least $24 \mathrm{~h}$, and processed for routine paraffin histology. Paraffin sections were stained with hematoxylin and eosin using routine procedures and samples were visualized under a Motic AE2000 microscope.

\subsection{Statistical}

Data are presented as means \pm standard deviation (SD) or the standard error of the mean (SEM). Statistical analysis was performed using the unpaired two-tailed $t$ test for two groups and analysis of variance for multiple groups. $P$ values $<0.05$ were considered statistically significant.

\section{Results}

\subsection{Effects of DEPTOR on inflammatory cytokines in mouse liver-derived Hepa1-6 cells} pcDNA3.1or pcDNA3.1-DEPTOR vectors were transfected to mouse liver-derived Hepa1-6 cells, and after $12 \mathrm{~h}$, the cells were treated with/without LPS ( $1 \mu \mathrm{g} / \mathrm{ml})$ for $12 \mathrm{~h}$. qRT-PCR was used to measure expression of inflammatory cytokines, including $T N F-\alpha, I L-1 \beta, I L-6, M C P-1$, and $p 65$. DEPTOR over-expression significantly promoted $I L-6$ and $M C P-1$ mRNA expression and strengthened LPS-induced these cytokines expression, and did not obviously up-regulated the mRNA levels of $T N F-\alpha, I L-1 \beta$ or $p 65$ (Figure 1A). In contrast, when Hepa1-6 cells were 
transfected with sh-control or sh-DEPTOR vectors, and after $36 \mathrm{~h}$, treated with/without LPS (1 $\mu \mathrm{g} / \mathrm{ml}$ ) for $12 \mathrm{~h}$, DEPTOR knock-down reduced $M C P-1$ and p65 mRNA expression, but had little effect on these cytokines in LPS stimulation, and had no obviously down-regulated the mRNA levels of $T N F-\alpha, I L-1 \beta, I L-6$ (Figure 1B). Western blot showed that DEPTOR protein expression was reduced to $18 \%$ in sh-DEPTOR group compared to controls (Figure 1B).

Since many DEPTOR functions are associated with inhibition of mTOR activity. Rapamycin, a specific inhibitor of mTORC1, was used to assess the effect of mTORC1 on inflammation. We pretreated Hepa1-6 cells with DMSO or rapamycin (100 nM for $30 \mathrm{~min}$ ), and then added LPS (1 $\mu \mathrm{g} / \mathrm{ml}$ for $8 \mathrm{~h}$ ). Figure $1 \mathrm{C}$ shows that rapamycin inhibited the mRNA levels of SREBP1c and $\mathrm{C} / \mathrm{EBPa}$, which are two downstream gene of mTORC1, suggesting mTORC1 activity was inhibited by rapamycin. Rapamycin up-regulated $M C P-1 \mathrm{mRNA}$ level, but had no significant effects on TNF- $\alpha, I L-1 \beta, I L-6$, p65 or DEPTOR mRNA levels (Figure 1C and 1D). Thus, these data indicate that DEPTOR regulates inflammatory cytokines expression in hepatocytes at least partially via mTORC1 pathway.

\subsection{LPS down-regulats DEPTOR expression in Hepa1-6 cells}

To study whether LPS stimulation affects DEPTOR expression, the mRNA level of DEPTOR was measured in Hepa1-6 cells treated with LPS $(0,0.5,1,5 \mu \mathrm{g} / \mathrm{ml})$ for $12 \mathrm{~h}$. DEPTOR mRNA was decreased after LPS stimulation compared to control, but this was not dose 
dependent (Figure 2A). Next, we treated Hepa1-6 cells with LPS $(1 \mu \mathrm{g} / \mathrm{ml})$ for different time periods $(0,0.5,1,2,4,8,12,24 \mathrm{~h}) . T N F-\alpha$ mRNA was rapidly increased and peaked at $1 \mathrm{~h}$ (Figure 2B) and DEPTOR mRNA was slightly decreased during 0 to $2 \mathrm{~h}$, and significantly reduced to $46.0 \%$ at $4 \mathrm{~h}$ and then stabilized (Figure 2C). Hepa1-6 cells were treated with LPS(1

$\mu \mathrm{g} / \mathrm{ml})$ for different time periods $(0,15 \mathrm{~m}, 30 \mathrm{~m}, 1,2,4,8,12,24 \mathrm{~h})$, and mTORC1/2 signaling pathways and DEPTOR protein was assayed. Akt phosphorylation was increased during $15 \mathrm{~m}$ to $1 \mathrm{~h}$ and declined to baseline at $2 \mathrm{~h}$, and S6K1 phosphorylation was increased over a longer duration from $30 \mathrm{~m}$ to $8 \mathrm{~h}$ (Figure 2D). p65 protein was increased in a time-dependent manner and peaked at $4 \mathrm{~h}$, but DEPTOR protein was decreased in a time-dependent manner (Figure 2E). Thus, DEPTOR is down-regulatd by LPS in a time-dependent manner, and mTORC1/2 signaling pathways are activated in LPS-induced inflammation in Hepa1-6 cells.

\subsection{NF-кB down-regulats DEPTOR expression in Hepa1-6 cells after LPS stimulation}

Because NF- $\kappa$ B contributes to inflammation and is activated after LPS stimulation, we speculated that NF- $\kappa$ B may affect DEPTOR expression. Thus, Hepa1-6 cells were transfected with pcDNA3.1/pcDNA3.1-p65 vectors for $12 \mathrm{~h}$ and treated with/without LPS $(1 \mu \mathrm{g} / \mathrm{ml})$ for $12 \mathrm{~h}$. Data show that DEPTOR mRNA and protein was significantly decreased in the pcDNA3.1-p65 group compared to controls (Figure 3A, B). DEPTOR protein was declined more in p65 overexpressing cells after LPS stimulation (Figure 3B). NF- $\kappa \mathrm{B}$ is inactive when it's physical 
association with its inhibitor I $\kappa \mathrm{B} \alpha$. We next evaluated DEPTOR mRNA expression in Hepa1-6 cells transfected with pcDNA3.1/pcDNA3.1-I $\kappa B \alpha$ vectors for $12 \mathrm{~h}$ and treated with/without LPS

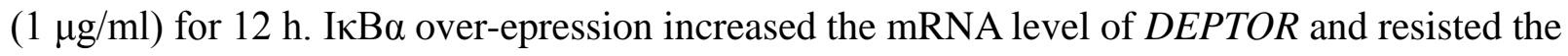
the effects of LPS (Figure 3C). Furthermore, PDTC, an NF- $\kappa$ B inhibitor, was applied to the cell culture and reduced LPS effects (Figure 3D).

\section{4. p65 binds to the DEPTOR promoter to reduce its activity}

$\mathrm{NF}-\kappa \mathrm{B}$ is a transcription factor so we investigated whether DEPTOR is down-regulatd via a transcriptional mechanism. With bioinformatic analysis, both promoters of Murine and Homo DEPTOR had several NF- $\mathrm{B}$ binding sites (Figure 4A). CHIP analysis with Hepa1-6 cells treated with/without LPS stimulation allowed assessment of NF- $\mathrm{BB}$ binding to three putative response sites (-2303/-2289, -1780/-1771, -145/-127) in the DEPTOR promoter. DNA gel images revealed that the $-145 /-127$ region was enriched with p65 binding compared to control IgG (Figure 4B). Quantitative analysis of CHIP samples with real time PCR confirmed that LPS stimulation promoted p65 binding to the DEPTOR promoter (Figure 4C).

To learn whether $\mathrm{p} 65$ regulates $D E P T O R$ promoter activity, luciferase activity analysis was performed. First, we measured activity of different lengths of DEPTOR promoters (-2391/+14, 2274/+14, -294/+14) (Figure 4D). Then, HEK293 cells co-transfected with pGL3-DEPTOR (2391/+14)/(-2274/+14)/(-294/+14)/mut (-294/+14) vectors and pcDNA3.1 or pcDNA3.1-p65 vectors were measured for luciferase activity. Data show that p65 had no visible effect on 
luciferase activity of pGL3-DEPTOR (-2391/+14), and significantly inhibited luciferase activity of pGL3-DEPTOR (-2274/+14)/(-294/+14), but not the pGL3-DEPTOR (-294/+14) mutation (Figure 4E). Taken together, p65 down-regulats DEPTOR expression by binding to the DEPTOR promoter at the $-145 /-127$ region and this is enhanced with LPS stimulation.

\subsection{LPS inhibits DEPTOR expression and activates the mTOR signaling pathway in mouse livers}

To assess DEPTOR participation in inflammation in vivo, we established an inflammatory C57BL/6 mouse model with LPS (10mg/kg, ip), in which hepatic Kupffer cells were obviously increased and serum TNF- $\alpha$ level was higher, compared with controls (Figure 5A, B). Inflammatory cytokines $T N F-\alpha, I L-1 \beta, I L-6$, and $I L-10 \mathrm{mRNA}$ expression were increased or on the up trend in LPS groups (Figure S1). Thus, the inflammatory model was successfully established. Using this model, we measured DEPTOR mRNA level in different tissues and noted that it was significantly less in the liver and visceral fat in LPS groups. It was also less in muscle but there was no significant difference between LPS groups and controls (Figure 5C). Western blot analysis showed that hepatic DEPTOR protein was significantly decreased, which was accompanied by a concurrent phosphorylation increase of S6K1 and Akt implying mTORC1/2 signaling pathways activation (Figure 5D and 5E). 


\section{Discussion}

The liver is continuously exposed to pathogens, toxins and toxicants, and dietary antigens from the intestine which can trigger inflammation and disease(Racanelli and Rehermann, 2006; Miyake and Yamamoto, 2013). Inflammation is a complex defence mechanism in which proinflammation and antiinflammation exists to return pathological organ to homeostasis. Insufficient inflammatory response results in immunodeficiency, while excessive inflammatory response cause morbidity and mortality(Tracey, 2002). DEPTOR is firstly reported to be associated with inflammation in vascular endothelial cells. DEPTOR is down-regulatd by the inflammatory cytokine TNF- $\alpha$ in human microvascular endothelial cells(Bruneau et al., 2013). Meng's group reported that DEPTOR is down-regulated in skeletal muscle in obesity. Further study demonstrated that DEPTOR is inhibited by TNF- $\alpha$ but not IL- 6 or myostatin (Mstn) through the ERK pathway in C2C12 myotubes(Meng et al., 2014). Consistent with these data, we observed DEPTOR was down-regulatd by inflammatory stimuli LPS in hepatocytes in vitro and in vivo. In vitro, we confirmed that both DEPTOR mRNA and protein levels were reduced in LPS treated Hepa1-6 cells compared to controls. In vivo, with an LPS-induced inflammatory mouse model to simulate liver insult, we noted that DEPTOR expression was significant decreased in mouse livers and visceral fat and less in mouse muscle after LPS treatment $12 \mathrm{~h}$. However, over-expression of DEPTOR in Hepa1-6 cells increased $I L-6$ and $M C P-1 \mathrm{mRNA}$ expression and enhanced LPS-induced these cytokines expression. DEPTOR knockdown in Hepa1-6 cells reduced $M C P-1$ mRNA but failed to reverse LPS stimulation, suggesting that DEPTOR may be one of LPS target genes. Furthermore, we also treated macrophages (RAW264.7 cells) with LPS and noted that DEPTOR mRNA was down-regulatd by LPS (data 
not shown). Thus, our data suggest that DEPTOR participates in LPS-induced inflammation in liver, visceral fat and muscle.

mTOR, as an evolutionarily conserved serine/threonine protein kinase, regulates multiple biological processes involved in mRNA translation, ribosome biogenesis, cell growth and proliferation, cell survival, and autophagy(Laplante and Sabatini, 2012), as well as influences inflammation(Dan et al., 2008; Fielhaber et al., 2012; Jiang et al., 2014; Gao et al., 2015; Yin et al., 2015; Song, 2010). DEPTOR is an intrinsic inhibitor of mTOR, and involves in inflammation, so we speculate that DEPTOR influences inflammation via mTOR pathways. After treating Hepa1-6 cells with/without rapamycin or LPS, we observed that rapamycin increased $M C P-1$ expression but did not change $I L-6$ expression. Rapamycin is a common inhibitor of mTORC1, but it can not block all aspects of mTORC1 functions(Choo et al., 2008; Feldman et al., 2009; Alam et al., 2015). Therefore, our data indicate that DEPTOR promotes inflammation at least partially via mTORC1 signaling pathways.

Although DEPTOR expression is reported to be regulated by mTOR signals and the ERK pathway at translational/post-translational levels, its regulatory mechanism of transcription is poorly studied presently(Peterson et al., 2009; Duan et al., 2011; Gao et al., 2011; Zhao et al., 2011; Meng et al., 2014). NF- $\mathrm{B}$ can be activated by LPS or inflammatory cytokine such as TNF- $\alpha$ or IL-1. It plays an important role in inflammation vis promoting transcription of inflammatory factors(Baldwin, 1996; Tak and Firestein, 2001). p65, an active subunit of NF-kB, reduced the levels of DEPTOR mRNA and protein in the current study. Both of NF- $\kappa$ B inhibitors $\mathrm{I} \kappa \mathrm{B} \alpha$ and PDTC can block DEPTOR down-regulation by LPS. Bioinformatic analysis revealed the presence of several conserved NF- $\mathrm{B}$ binding sites in murine and Homo DEPTOR promoter. Luciferase activity analysis indicated that murine DEPTOR promoter activity is controlled by 
p65. ChIP analysis revealed that p65 directly bound to the murine DEPTOR promoter at the 145/-127 region and this combination was enhanced under LPS stimulation condition. In general, DEPTOR is down-regulatd by LPS through the NF- $\kappa$ B pathway at the transcriptional level. In addition, we observed that the decline of DEPTOR protein prior to the reduction of DEPTOR mRNA, so speculated that LPS also regulates DEPTOR at post-transcriptional level.

\section{Conclusion}

LPS down-regulats DEPTOR expression via p65 binding to DEPTOR promoter at the 145/-127 region. Whereas, DEPTOR over-expression promotes $I L-6$ and $M C P-1$ mRNA expression. mTOR special inhibitor rapamycin increases $M C P-1$ mRNA expression, suggesting that DEPTOR plays an important role in regulating liver inflammatory response at least partially via mTOR signaling pathway.

\section{Acknowledgements}

This work was supported by the grants from National key Basic Research Program of China (2012CB124702), 948 Program of China (2015-Z33), Specialized Research Fund for the Doctoral Program of Higher Education (20110146130002), Program of National Natural Science Foundation of China (31172093, 31572382, 31372418), the National Science Foundation for Fostering Talents in Basic Research (J1103510), the Fundamental Research Funds for the Central Universities (2013PY005, 2013PY131). 


\section{Reference}

Agrawal, P., Reynolds, J., Chew, S., Lamba, D.A. and Hughes, R.E., 2014. DEPTOR is a stemness factor that regulates pluripotency of embryonic stem cells. J Biol Chem 289, 31818-26.

Alam, M., Khan, M., Veledar, E., Pongprutthipan, M., Flores, A., Dubina, M., Nodzenski, M. and Yoo, S.S., 2015. Correlation of Inflammation in Frozen Sections With Site of Nonmelanoma Skin Cancer. JAMA Dermatol, 1-4.

Baker, R.G., Hayden, M.S. and Ghosh, S., 2011. NF-kappaB, inflammation, and metabolic disease. Cell Metab 13, 11-22.

Baldwin, A.S., Jr., 1996. The NF-kappa B and I kappa B proteins: new discoveries and insights. Annu Rev Immunol 14, 649-83.

Bruneau, S., Nakayama, H., Woda, C.B., Flynn, E.A. and Briscoe, D.M., 2013. DEPTOR regulates vascular endothelial cell activation and pro-inflammatory and angiogenic responses. Blood 122, 1833-42.

Choo, A.Y., Yoon, S.O., Kim, S.G., Roux, P.P. and Blenis, J., 2008. Rapamycin differentially inhibits S6Ks and 4E-BP1 to mediate cell-type-specific repression of mRNA translation. Proc Natl Acad Sci U S A 105, 17414-9.

Dan, H.C., Cooper, M.J., Cogswell, P.C., Duncan, J.A., Ting, J.P. and Baldwin, A.S., 2008. Aktdependent regulation of NF-\{kappa\}B is controlled by mTOR and Raptor in association with IKK. Genes Dev 22, 1490-500.

Doig, C.L., Bashir, J., Zielinska, A.E., Cooper, M.S., Stewart, P.M. and Lavery, G.G., 2014. TNFalpha-mediated Hsd11b1 binding of NF-kappaB p65 is associated with suppression of 11beta-HSD1 in muscle. J Endocrinol 220, 389-96.

Duan, S., Skaar, J.R., Kuchay, S., Toschi, A., Kanarek, N., Ben-Neriah, Y. and Pagano, M., 2011. mTOR generates an auto-amplification loop by triggering the betaTrCP- and CK1alphadependent degradation of DEPTOR. Mol Cell 44, 317-24.

Feldman, M.E., Apsel, B., Uotila, A., Loewith, R., Knight, Z.A., Ruggero, D. and Shokat, K.M., 2009. Active-site inhibitors of mTOR target rapamycin-resistant outputs of mTORC1 and mTORC2. PLoS Biol 7, e38.

Fielhaber, J.A., Carroll, S.F., Dydensborg, A.B., Shourian, M., Triantafillopoulos, A., Harel, S., Hussain, S.N., Bouchard, M., Qureshi, S.T. and Kristof, A.S., 2012. Inhibition of mammalian target of rapamycin augments lipopolysaccharide-induced lung injury and apoptosis. J Immunol 188, 4535-42.

Gao, D., Inuzuka, H., Tan, M.K., Fukushima, H., Locasale, J.W., Liu, P., Wan, L., Zhai, B., Chin, Y.R., Shaik, S., Lyssiotis, C.A., Gygi, S.P., Toker, A., Cantley, L.C., Asara, J.M., Harper, J.W. and Wei, W., 2011. mTOR drives its own activation via SCF(betaTrCP)-dependent degradation of the mTOR inhibitor DEPTOR. Mol Cell 44, 290-303.

Gao, S.S., Liu, W.M., Zhuo, X.D., Wang, L.J., Wang, G., Sun, T., Zhao, Z., Liu, J.H., Tian, Y.L., Zhou, J., Yuan, Z.Y. and Wu, Y., 2015. The activation of mTOR is required for monocyte pro-inflammatory response in patients with coronary artery disease. Clinical Science 128, 517-526.

Grivennikov, S.I., Greten, F.R. and Karin, M., 2010. Immunity, inflammation, and cancer. Cell 140, 883-99.

Hotamisligil, G.S., 2006. Inflammation and metabolic disorders. Nature 444, 860-7. 
Jiang, H., Westerterp, M., Wang, C., Zhu, Y. and Ai, D., 2014. Macrophage mTORC1 disruption reduces inflammation and insulin resistance in obese mice. Diabetologia 57, 2393-404.

Kotas, M.E. and Medzhitov, R., 2015. Homeostasis, inflammation, and disease susceptibility. Cell $160,816-27$.

Laplante, M., Horvat, S., Festuccia, W.T., Birsoy, K., Prevorsek, Z., Efeyan, A. and Sabatini, D.M., 2012. DEPTOR cell-autonomously promotes adipogenesis, and its expression is associated with obesity. Cell Metab 16, 202-12.

Laplante, M. and Sabatini, D.M., 2012. mTOR signaling in growth control and disease. Cell 149, 274-93.

Lee, D.F., Kuo, H.P., Chen, C.T., Hsu, J.M., Chou, C.K., Wei, Y., Sun, H.L., Li, L.Y., Ping, B., Huang, W.C., He, X., Hung, J.Y., Lai, C.C., Ding, Q., Su, J.L., Yang, J.Y., Sahin, A.A., Hortobagyi, G.N., Tsai, F.J., Tsai, C.H. and Hung, M.C., 2007. IKK beta suppression of TSC1 links inflammation and tumor angiogenesis via the mTOR pathway. Cell 130, 44055.

Lisa M. Coussens, Z.W., 2002. Inflammation and cancer. Nature 420, 860-867.

Mantovani, A., Allavena, P., Sica, A. and Balkwill, F., 2008. Cancer-related inflammation. Nature $454,436-44$.

Meng, Z.X., Wang, L., Xiao, Y. and Lin, J.D., 2014. The Baf60c/Deptor pathway links skeletal muscle inflammation to glucose homeostasis in obesity. Diabetes 63, 1533-45.

Mimura, Y., Sakisaka, S., Harada, M., Sata, M. and Tanikawa, K., 1995. Role of hepatocytes in direct clearance of lipopolysaccharide in rats. Gastroenterology 109, 1969-76.

Miyake, Y. and Yamamoto, K., 2013. Role of gut microbiota in liver diseases. Hepatol Res 43, 139-46.

Nemeth, E., Baird, A.W. and O'Farrelly, C., 2009. Microanatomy of the liver immune system. Semin Immunopathol 31, 333-43.

Peterson, T.R., Laplante, M., Thoreen, C.C., Sancak, Y., Kang, S.A., Kuehl, W.M., Gray, N.S. and Sabatini, D.M., 2009. DEPTOR is an mTOR inhibitor frequently overexpressed in multiple myeloma cells and required for their survival. Cell 137, 873-86.

Racanelli, V. and Rehermann, B., 2006. The liver as an immunological organ. Hepatology 43, S54-62.

Sarbassov, D.D., Ali, S.M., Sengupta, S., Sheen, J.H., Hsu, P.P., Bagley, A.F., Markhard, A.L. and Sabatini, D.M., 2006. Prolonged rapamycin treatment inhibits mTORC2 assembly and Akt/PKB. Mol Cell 22, 159-68.

Scott, M.J. and Billiar, T.R., 2008. Beta2-integrin-induced p38 MAPK activation is a key mediator in the CD14/TLR4/MD2-dependent uptake of lipopolysaccharide by hepatocytes. J Biol Chem 283, 29433-46.

Song, X., Kusakari, Y., Xiao, C., Kinsella, S.D., Rosenberg, M.A., Crosbie, M.S., Hara,K., X., Kusakari, Y., Xiao.C., Kinsella, S.D., Rosenberg, M.A., Crosbie, M.S., Hara, K., 2010. mTOR attenuates the inflammatory response in cardiomyocytes and prevents cardiac dysfunction in pathological hypertrophy. Am J Physiol Cell Physiol 299, C1256-C1266.

Tak, P.P. and Firestein, G.S., 2001. NF-kappaB: a key role in inflammatory diseases. J Clin Invest 107, 7-11.

Tracey, K.J., 2002. The inflammatory reflex. Nature 420, 853-9.

Treon, S.P., Thomas, P. and Broitman, S.A., 1993. Lipopolysaccharide (LPS) processing by Kupffer cells releases a modified LPS with increased hepatocyte binding and decreased tumor necrosis factor-alpha stimulatory capacity. Proc Soc Exp Biol Med 202, 153-8. 
Yin, J., Gu, L., Wang, Y., Fan, N., Ma, Y. and Peng, Y., 2015. Rapamycin improves palmitateinduced ER stress/NF kappa B pathways associated with stimulating autophagy in adipocytes. Mediators Inflamm 2015, 272313.

Zhang, H., Chen, J., Zeng, Z., Que, W. and Zhou, L., 2013a. Knockdown of DEPTOR induces apoptosis, increases chemosensitivity to doxorubicin and suppresses autophagy in RPMI8226 human multiple myeloma cells in vitro. Int J Mol Med 31, 1127-34.

Zhang, H.R., Chen, J.M., Zeng, Z.Y. and Que, W.Z., 2013b. Knockdown of DEPTOR inhibits cell proliferation and increases chemosensitivity to melphalan in human multiple myeloma RPMI-8226 cells via inhibiting PI3K/AKT activity. J Int Med Res 41, 584-95.

Zhao, Y., Xiong, X. and Sun, Y., 2011. DEPTOR, an mTOR inhibitor, is a physiological substrate of SCF(betaTrCP) E3 ubiquitin ligase and regulates survival and autophagy. Mol Cell 44, 304-16. 


\section{Captions of figures}

Fig.1 DEPTOR increases the expression of inflammatory cytokine in hepa1-6 cells.

(A) Hepa1-6 cells were transfected with pcDNA3.1/pcDNA3.1-DEPTOR, after $12 \mathrm{~h}$, treated with/without LPS for $12 \mathrm{~h}$. The cells were collected for qRT-PCR analysis.

(B) Hepa1-6 cells were transfected with pSilencer4.1 CMV/ pSilencer4.1 CMV-DEPTOR (shcontrol/sh-DEPTOR) vectors, after $36 \mathrm{~h}$, treated with/without LPS for $12 \mathrm{~h}$. Inflammatory cytokines were measured by qRT-PCR. Western blot of total protein lysates from Hepa1-6 cells transfected with sh-control/sh-DEPTOR vectors for $48 \mathrm{~h}$.

(C-D) Hepa1-6 cells pre-incubated with/without rapamycin (mTOR inhibitor, $100 \mathrm{nM}$ ), and after $30 \mathrm{~min}$, treated with /without LPS $(1 \mu \mathrm{g} / \mathrm{ml})$ for $8 \mathrm{~h}$. mRNA was measured by qRT-PCR.

Data are presented as means \pm SEM. Values with different letters are significantly different $(P<$ 0.05). Data represent at least three independent experiments.

Fig. 2 Downregulation of DEPTOR by LPS stimulation in Hepa1-6 cells.

(A) DEPTOR mRNA level was measured by qRT-PCR in Hepa1-6 cells treated with LPS (0, $0.5,1,5 \mu \mathrm{g} / \mathrm{ml})$ for $12 \mathrm{~h}$.

(B-C) DEPTOR and TNA- $\alpha$ mRNA were measured by qRT-PCR in Hepa1-6 cells treated with LPS $(1 \mu \mathrm{g} / \mathrm{ml})$ for different time periods $(0,0.5,1,2,4,8,12,24 \mathrm{~h})$.

(D-E) Western blot of total protein lysates from Hepa1-6 cells treated with LPS (1 $\mu \mathrm{g} / \mathrm{ml})$ for different time periods $(0,15 \mathrm{~m}, 30 \mathrm{~m}, 1,2,4,8,12,24 \mathrm{~h})$. The fold change in p65 and DEPTOR following LPS treatment relative to control determined by density analysis is shown below the panels. 
Data are presented as means \pm SEM. Values with different letters are significantly different $(P$ $<0.05), * P<0.05, * * P<0.01$.*** $P<0.0001$. All data represent at least three independent experiments.

Fig. 3 Downregulation of DEPTOR by LPS through NF-кB in Hepa1-6 cells.

(A) DEPTOR mRNA level was measured by qRT-PCR in Hepa1-6 cells transfected with pcDNA3.1/pcDNA3.1-p65 vectors for $24 \mathrm{~h}$.

(B) Western blot of total protein lysates from Hepa1-6 cells transfected with pcDNA3.1/pcDNA3.1-p65 vectors for $12 \mathrm{~h}$, and then treated with or without LPS $(1 \mu \mathrm{g} / \mathrm{ml})$ for $12 \mathrm{~h}$. The fold change of DEPTOR in groups transfected with pcDNA3.1/pcDNA3.1-p65 vectors following LPS treatment relative to control determined by density analysis is shown below the panels.

(C) Hepa1-6 cells were transfected with pcDNA3.1/pcDNA3.1- I $\kappa B \alpha$ vectors for $12-\mathrm{h}$, and then treated with or without LPS $(1 \mu \mathrm{g} / \mathrm{ml})$ for $12 \mathrm{~h}$. DEPTOR mRNA level was measured by qRTPCR.

(D) Hepa1-6 cells pre-incubation with or without PDTC (inhibitor of NF- $\kappa \mathrm{B}, 10 \mu \mathrm{M}$ ), after 30 min, treated with or without LPS $(1 \mu \mathrm{g} / \mathrm{ml})$ for $2 \mathrm{~h}$ or $4 \mathrm{~h}$, and DEPTOR mRNA were measured by qRT-PCR.

Data are presented as means \pm SEM. $* P<0.05, * * P<0.01$. *** $P<0.0001$. All data represent at least three independent experiments.

Fig.4 NF-кB binds to $D E P T O R$ promoter to reduce its activity. 
(A) Consensus sequences for the putative binding sites of $\mathrm{NF}-\kappa \mathrm{B}$ are black boxes.

(B) CHIP assays were conducted in Hepa1-6 cells treated with/without LPS for $12 \mathrm{~h}$. Putative binding sites of NF- $\mathrm{KB}$ in the DEPTOR promoter were amplified by PCR using pairs of aimed primers. IкB $\alpha$ was used as a positive control.

(C) CHIP samples of A were performed qRT-PCR and analyed with a fold enrichment method.

(D) Different lengths of DEPTOR promoters $(-2391 /+14,-2274 /+14,-294 /+14)$ were ligated to pGL3Basic vectors, which were co-transfected with Renilla luciferase reporter vectors into HEK293 cells. Twenty-four hours later, luciferase reporter activity was measured. Renilla luciferase reporter vector was used as an internal control to correct the transfection efficiency.

(E) pGL3-DEPTOR (-2391/+14) / (-2274/+14)/ (-294/+14) / (-294/+14) -mut vectors and Renilla luciferase reporter vectors were co-transfected with pcDNA3.1/pcDNA3.1-p65 into HEK293 cells. Twenty-four hours later, luciferase reporter activity was measured. pGL3DEPTOR (-294/+14) -mut is the DEPTOR promoter mutated as indicated. pcDNA3.1 vector was used as a vector control.

Data are presented as means \pm SEM from at least three independent experiments. ${ }^{*} P<0.05$, $* * P$ $<0.01$.

\section{Fig.5 LPS inhibits DEPTOR expression and activates the mTOR signaling pathway in} mouse livers. C57BL/6J mice were intraperitoneally injected LPS $(10 \mathrm{~g} / \mathrm{kg})$ or normal saline (control) for 12-h, and subjected to histological and gene expression analysis. 
(A) H\&E analysis liver sections. Right panels are 40x and left panels are 400x. Red boxes (right panels) are enlarged in the left panels. Arrows indicate macrophages recruitment.

(B) Serum TNA $\alpha$ was determined by ELISA $(n=7-8)$.

(C) DEPTOR mRNA was measured by qRT-PCR in liver, visceral fat, and muscle (n=3-4).

(D) Western blot of total protein lysates from liver $(n=5)$.

(E) Quantification of p-S6K1/S6K, p-Akt/Akt, DEPTOR/ $\beta$-action, p65/ $\beta$-action protein levels in $\mathrm{D}(\mathrm{n}=5)$.

Data are presented as means \pm SD. $* P<0.05, * * P<0.01$. 
Table 1. Primers used to perform PCR amplifications in this study.

\begin{tabular}{|c|c|c|c|}
\hline $\begin{array}{l}\text { Gene } \\
\text { Symbal }\end{array}$ & $\begin{array}{l}\text { Product } \\
\text { Size }(b p)\end{array}$ & $\begin{array}{l}\text { Forward primer }\left(5^{\prime}-3^{\prime}\right) \& \\
\text { Reverse primer }\left(5^{\prime}-3^{\prime}\right)\end{array}$ & Accession number \\
\hline Mus DEPTOR & 1230 & $\begin{array}{l}F: \text { ATGGAAGAGGGCAGCAG } \\
R: \text { TCAGCAGTCCAACTCCTCC }\end{array}$ & $N M \_145470.2$ \\
\hline $\begin{array}{l}\text { Mus DEPTOR }(-2391 /+14) \\
\text { Promoter }\end{array}$ & 2405 & 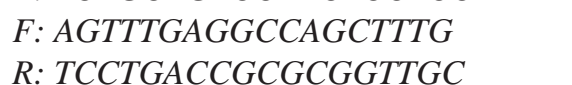 & Gene ID: 97998 \\
\hline $\begin{array}{l}\text { Mus DEPTOR }(-2274 /+14) \\
\text { promoter }\end{array}$ & 2288 & $\begin{array}{l}F: \text { TTTAGCCTTACATTGCAG } \\
R: \text { TCCTGACCGCGCGGTTGC }\end{array}$ & \\
\hline $\begin{array}{l}\text { Mus DEPTOR }(-294 /+14) \\
\text { promoter }\end{array}$ & 308 & $\begin{array}{l}F: \text { GAAAGGCTCAACCTCCTG } \\
R: \text { TCCTGACCGCGCGGTTGC }\end{array}$ & \\
\hline ChIP DEPTOR (-2303/-2289) & 161 & $\begin{array}{l}\text { F: GTGGAGGCAAGAGAATCAG } \\
R: A A A T T A C T G C A A T G T A A G G C\end{array}$ & \\
\hline ChIP DEPTOR (-1780/-1771) & 153 & $\begin{array}{l}F: C T G C A C A G A G A A A C C T T A C C \\
R: \text { ATGGAGAGAGGTTTCAGTTC }\end{array}$ & \\
\hline ChIP DEPTOR (-145/-127) & 213 & $\begin{array}{l}F: A A G C C G A A G T T C C A G A C C \\
R: C T G C C C T C T T C C A T G T T C C T G A C\end{array}$ & \\
\hline ChIP I $B \alpha$ & 290 & $\begin{array}{l}F: \text { TAGCCAGCGTTTCCACTCTT } \\
R: \text { GGTCATGCACAGGGAACTTT }\end{array}$ & Gene ID: 18036 \\
\hline
\end{tabular}

Table 2. Primers used to perform qRT-PCR amplifications in this study.

\begin{tabular}{|c|c|c|c|}
\hline $\begin{array}{l}\text { Gene } \\
\text { Symbal }\end{array}$ & $\begin{array}{l}\text { Product } \\
\text { Size (bp) }\end{array}$ & $\begin{array}{l}\text { Forward primer }\left(5^{\prime}-3^{\prime}\right) \& \\
\text { Reverse primer }\left(5^{\prime}-3^{\prime}\right)\end{array}$ & Accession number \\
\hline Mus $\beta$-action & 245 & $\begin{array}{l}\text { F: GTGACGTTGACATCCGTAAAGA } \\
R: \text { GCCGGACTCATCGTACTCC }\end{array}$ & NM_007393 \\
\hline Mus DEPTOR & 190 & $\begin{array}{l}\text { F: GTACGCAAGGAAGACATTCACG } \\
\text { R: CACGGTGCGGTAGTCTACATTC }\end{array}$ & $N M_{-} 145470.2$ \\
\hline Mus TNF $\alpha$ & 252 & $\begin{array}{l}\text { F: AGTGACAAGCCTGTAGCCC } \\
\text { R:GAGGTTGACTTTCTCCTGGTAT }\end{array}$ & NM_013693.3 \\
\hline Mus $I L-1 \beta$ & 124 & $\begin{array}{l}\text { F: CTGGTACATCAGCACCTCAC } \\
R: A G A A A C A G T C C A G C C C A T A C\end{array}$ & NM_008361.3 \\
\hline Mus IL-6 & 197 & $\begin{array}{l}F: T G T A T G A A C A A C G A T G A T G C A C T T \\
R: \text { ACTCTGGCTTTGTCTTTCTTGTTATCT }\end{array}$ & NM_031168.1 \\
\hline Mus IL-10 & 145 & $\begin{array}{l}F: G C C A G A G C C A C A T G C T C C T A \\
R: \text { GATAAGGCTTGGCAACCCAAGTAA }\end{array}$ & NM_010548.2 \\
\hline Mus p65 & 156 & $\begin{array}{l}\text { F: CCAGACACAGATGATCGCCAC } \\
\text { R: GACAGAAGTTGAGTTTCGGGTAGG }\end{array}$ & NM_009045.4 \\
\hline Mus $M C P-1$ & 173 & $\begin{array}{l}F: \text { GATGCAGTTAACGCCCCACT } \\
R: \text { ACCCATTCCTTCTTGGGGTC }\end{array}$ & NM_011333.3 \\
\hline
\end{tabular}



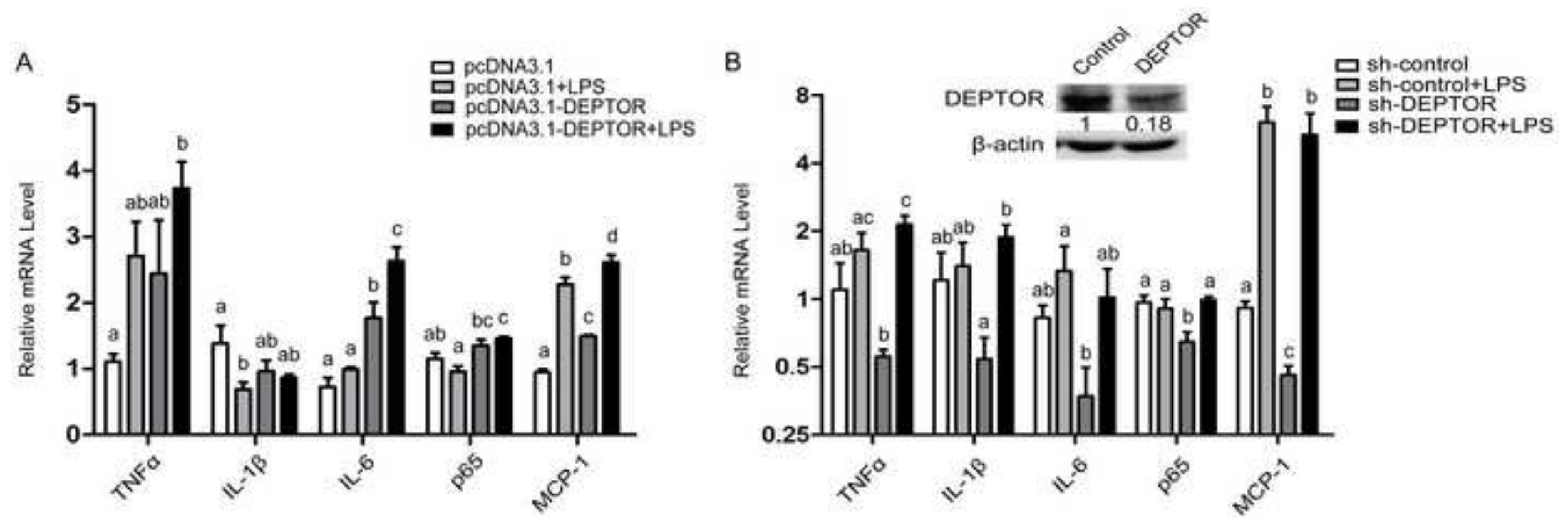

C

D

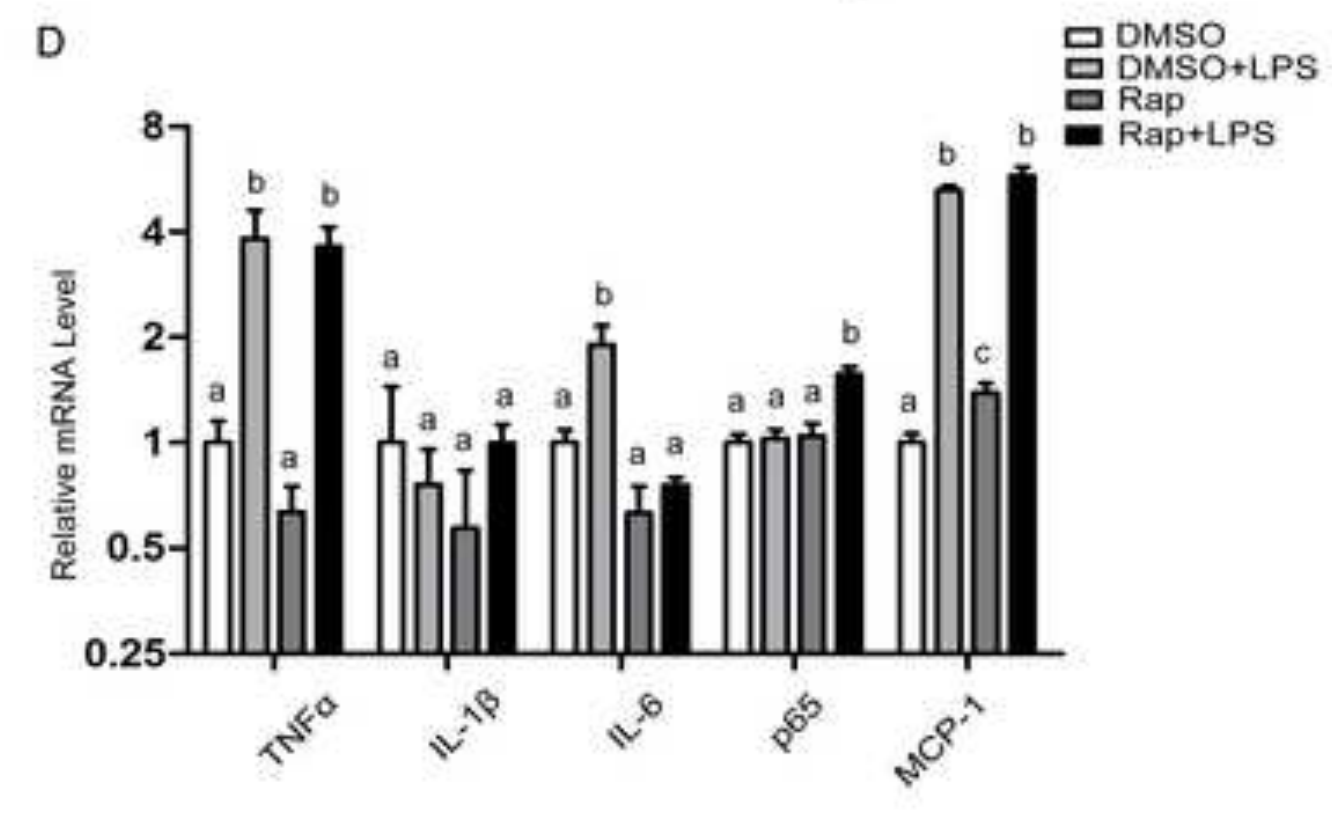


A

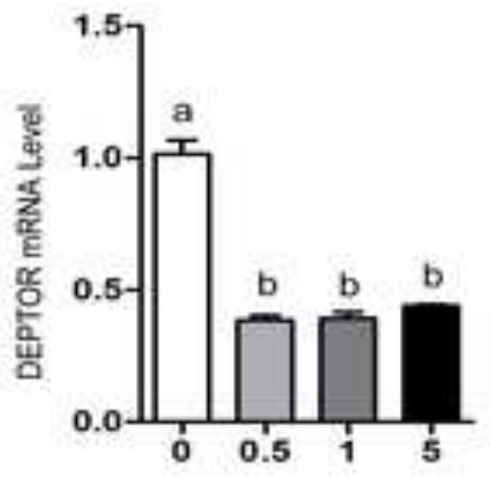

B

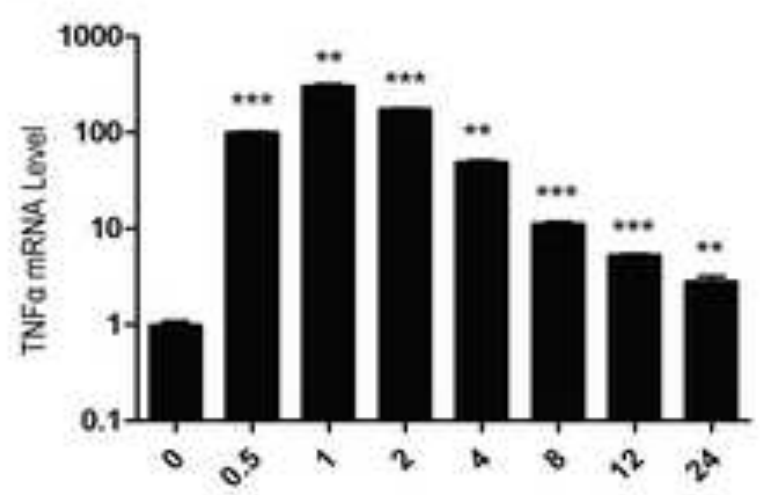

C

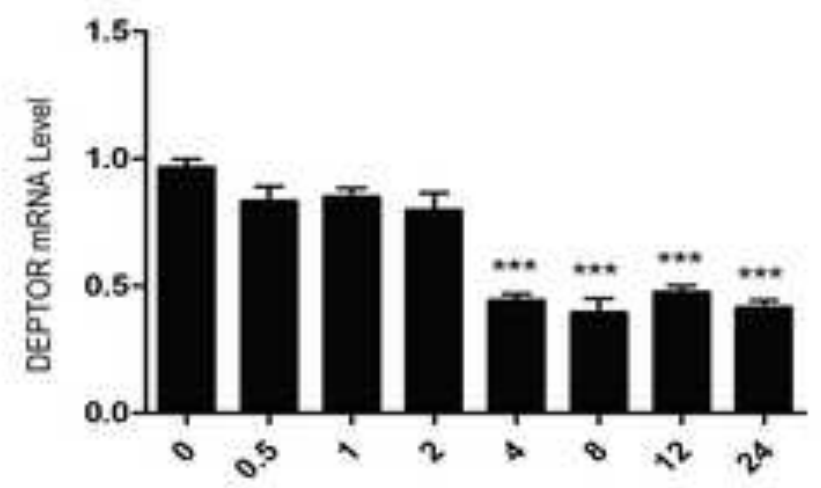

D

p-S6K1 T389

S6K1

p-Akt $\$ 473$

Akt

LPS

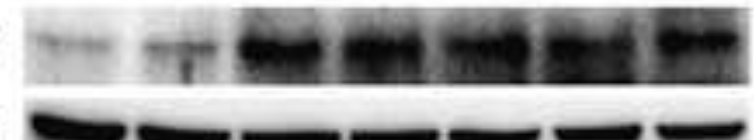

$--1-$
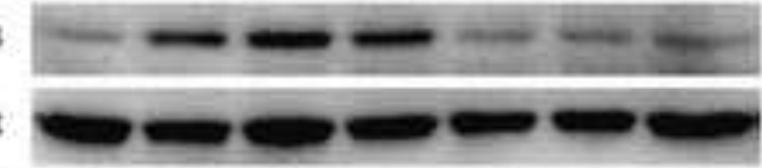

$015 m \quad 30 m$ 1h $2 h$ th $8 h$
E

DEPTOR

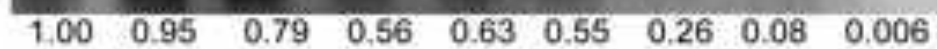

p65

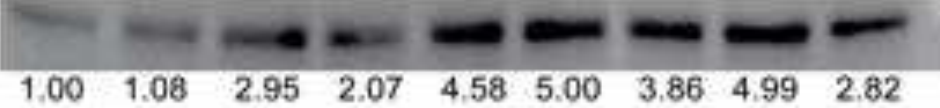

$\beta$-actin LPS 
A

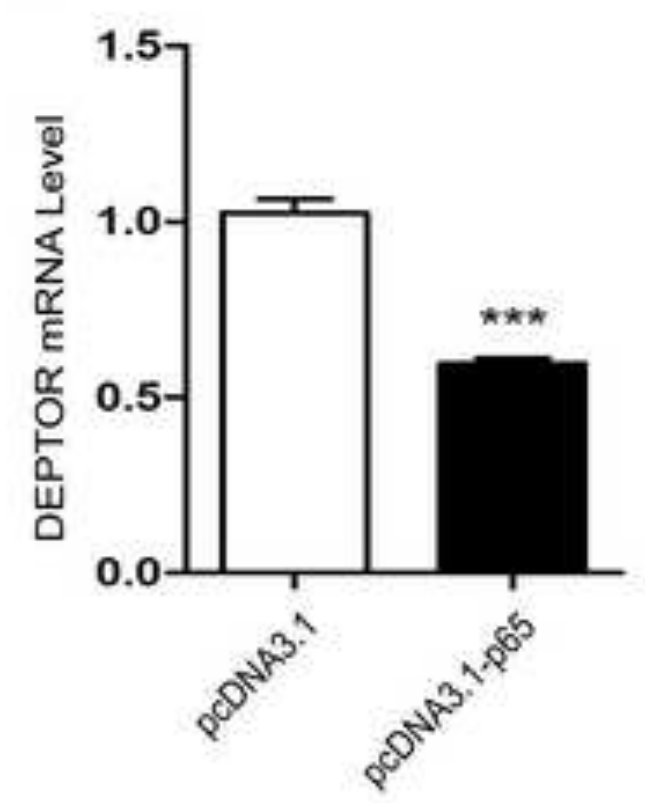

C

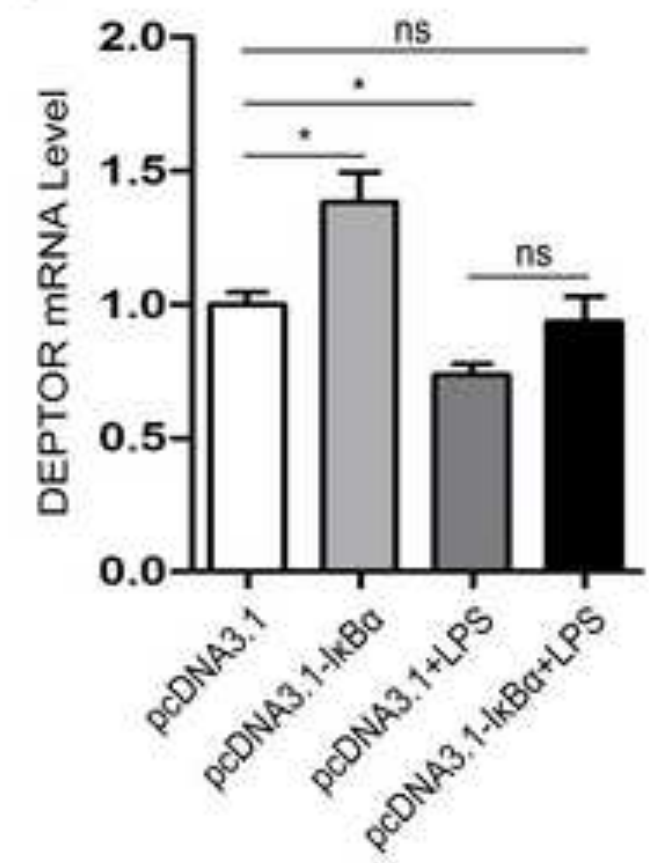

B

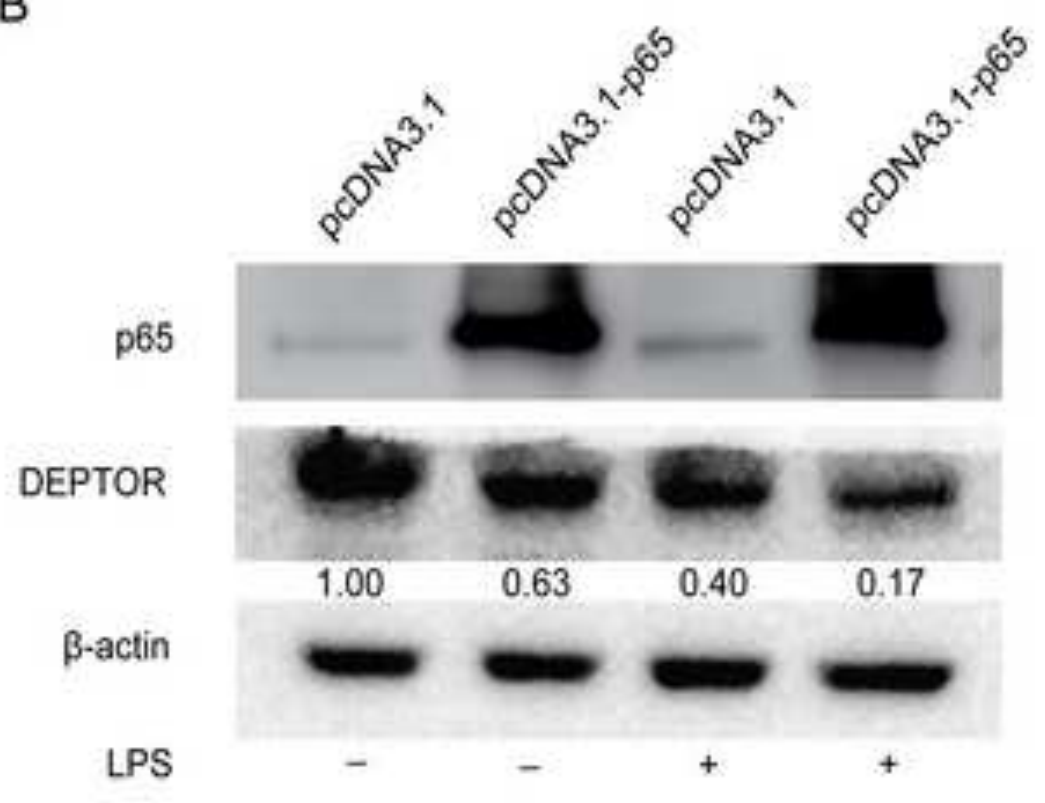

D

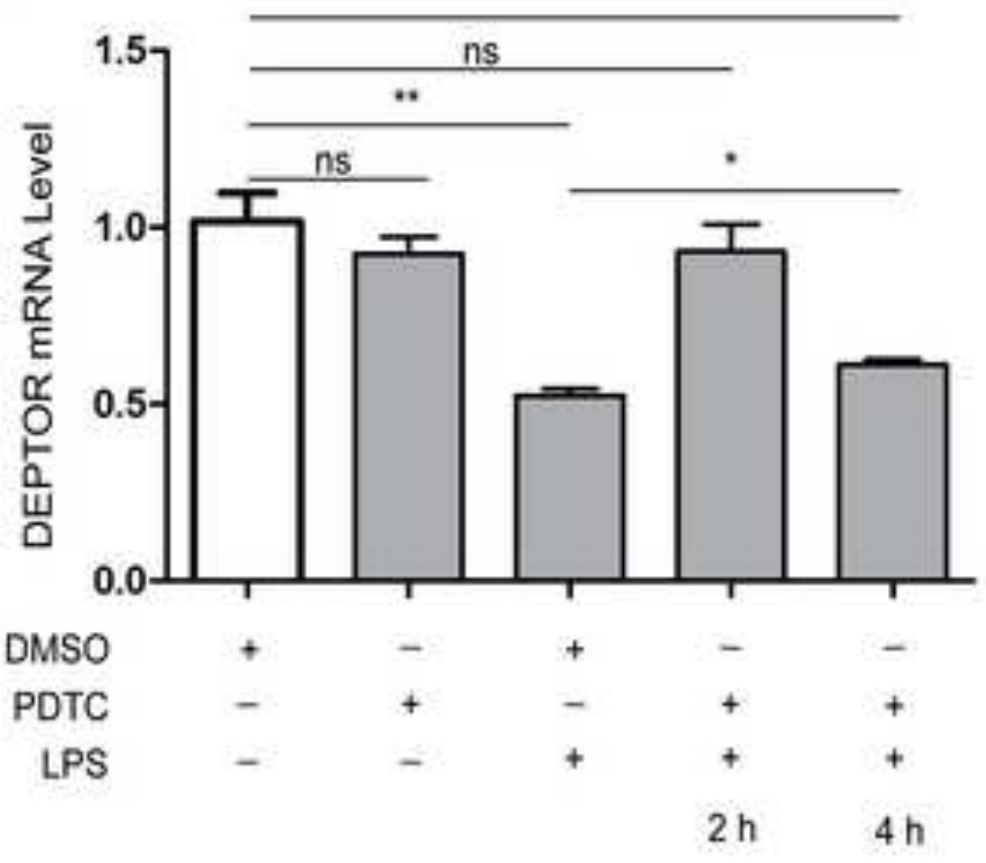


A

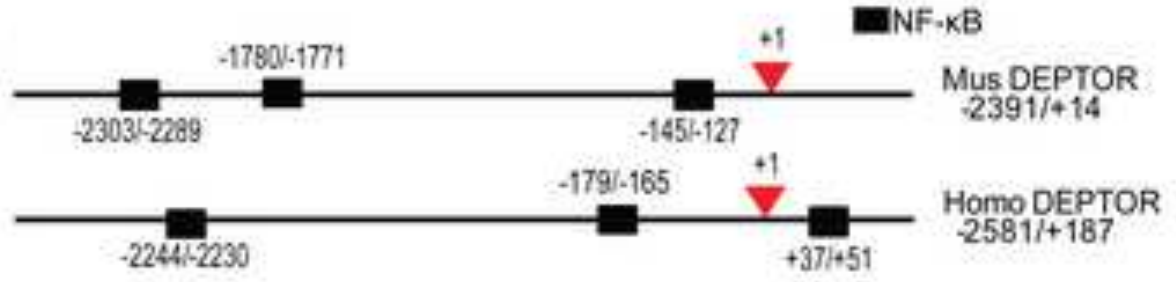

B

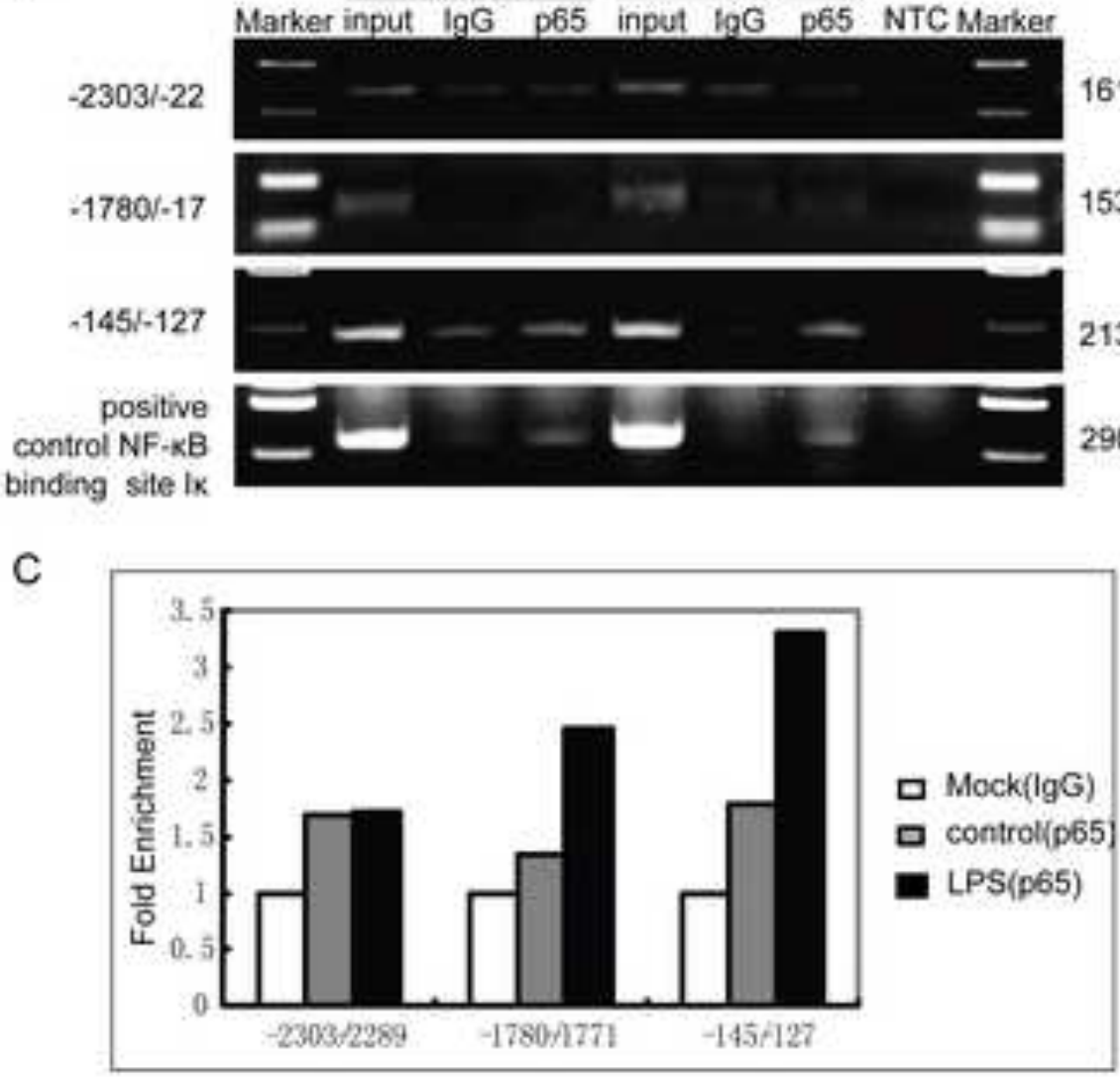

\section{1 bp}

153 bp

$213 b p$

$290 \mathrm{bp}$
D

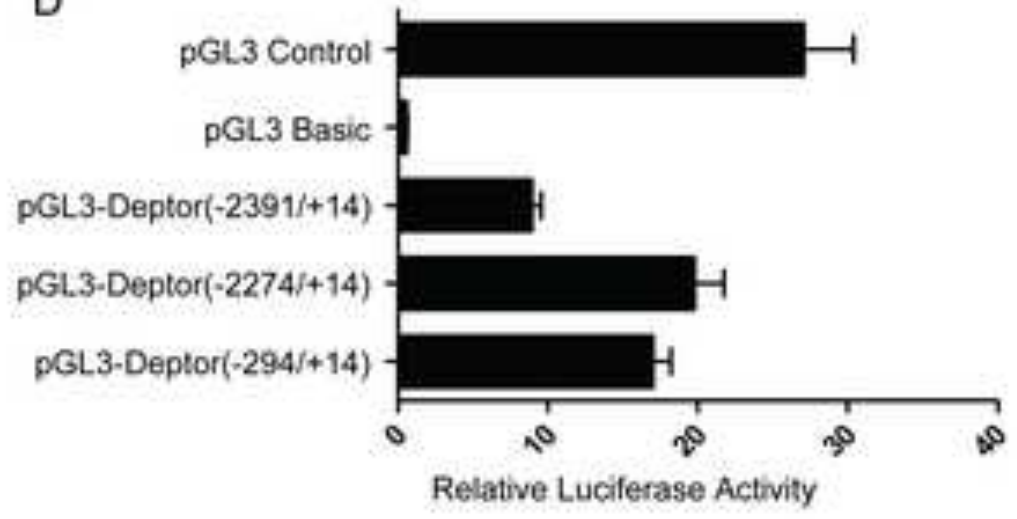

E
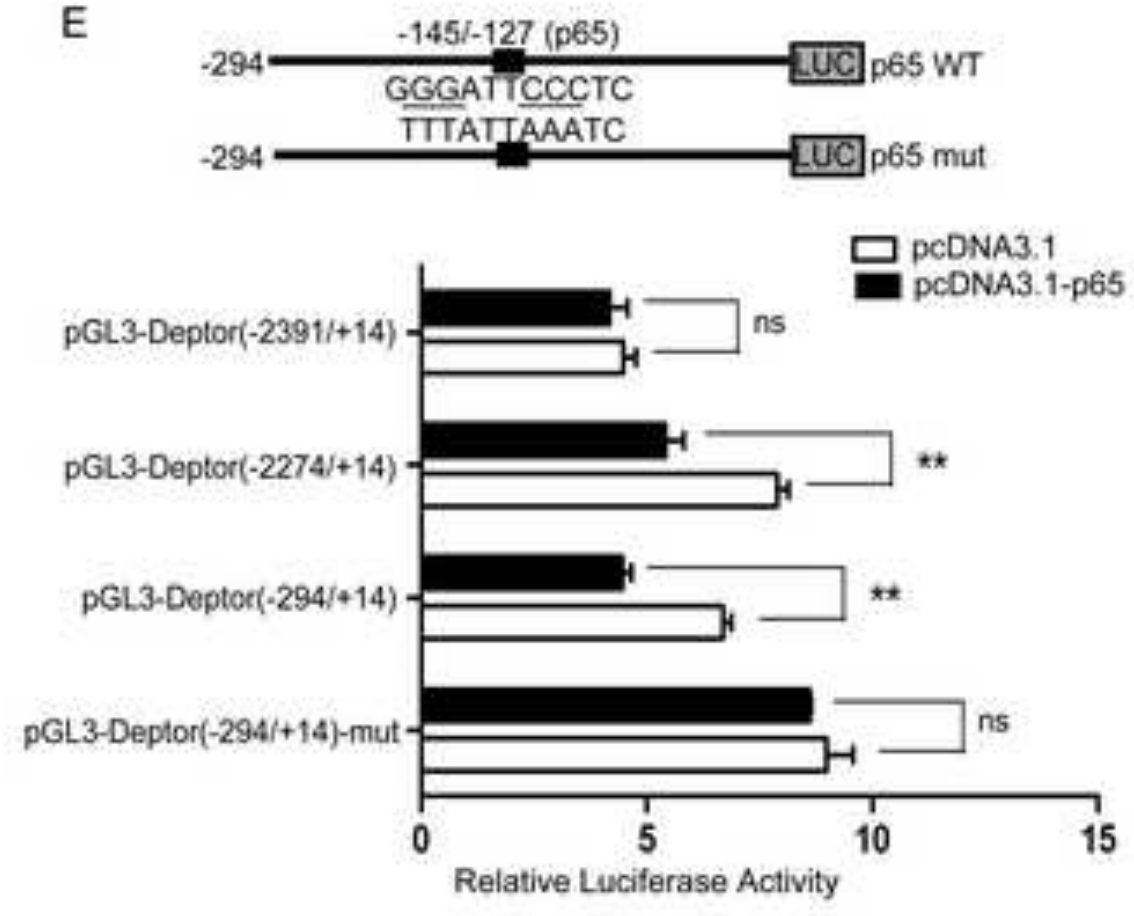
A

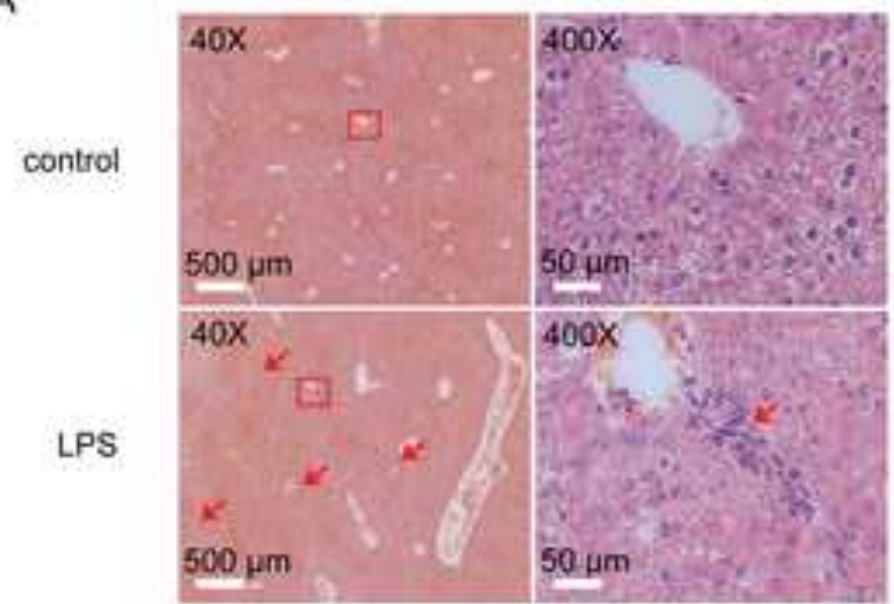

D

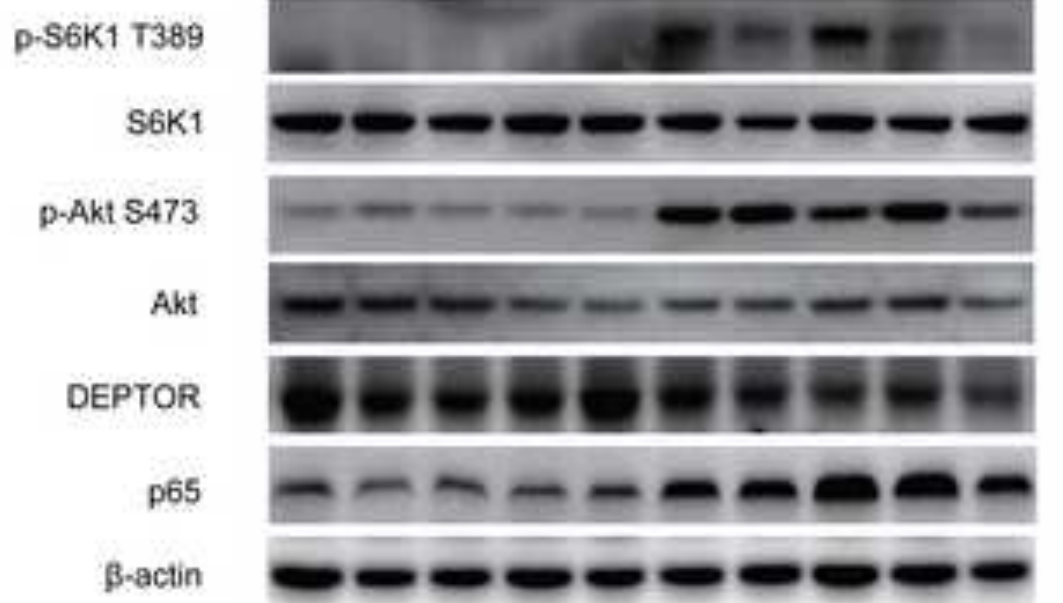

C

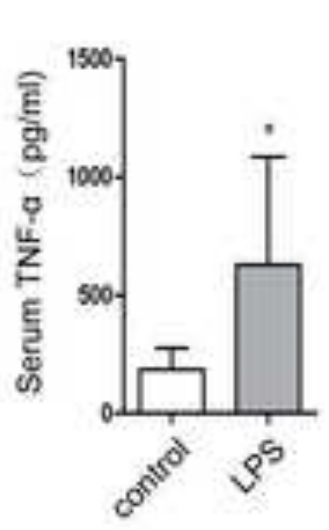

E

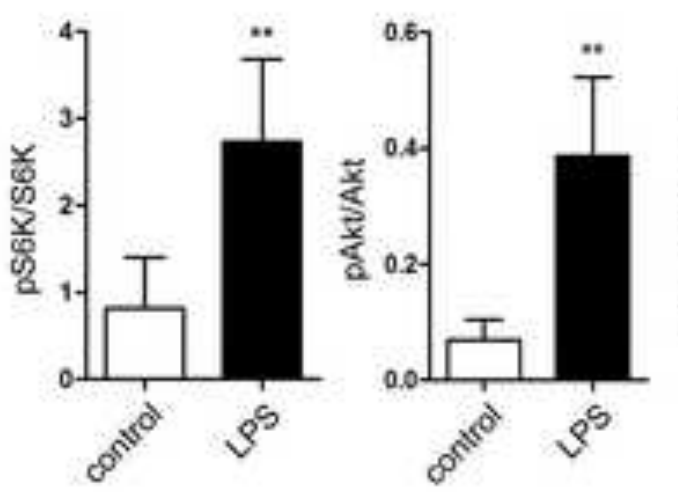

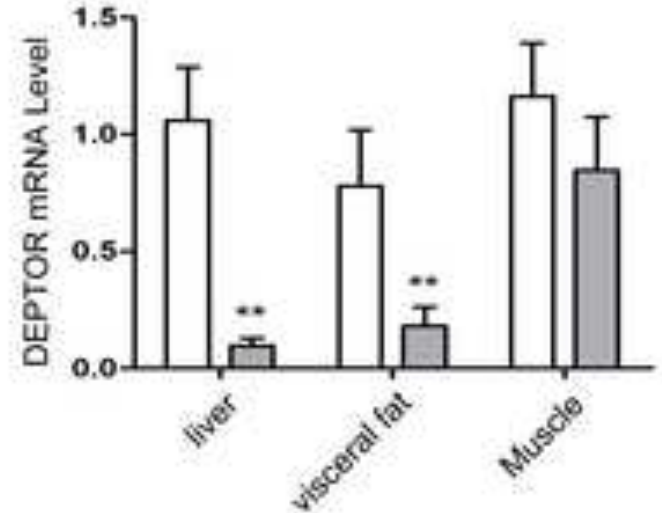
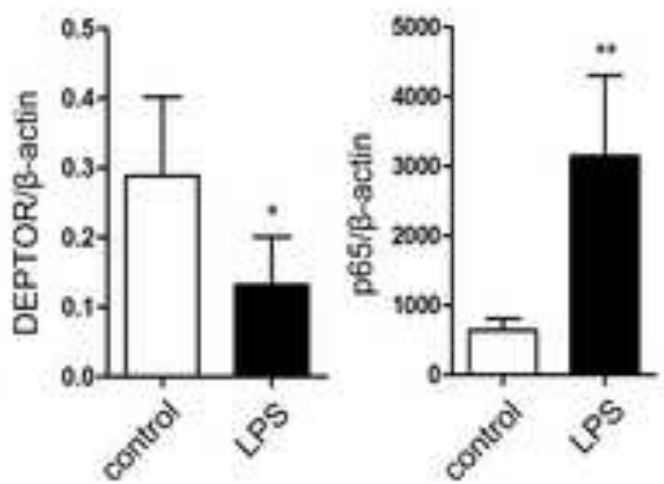

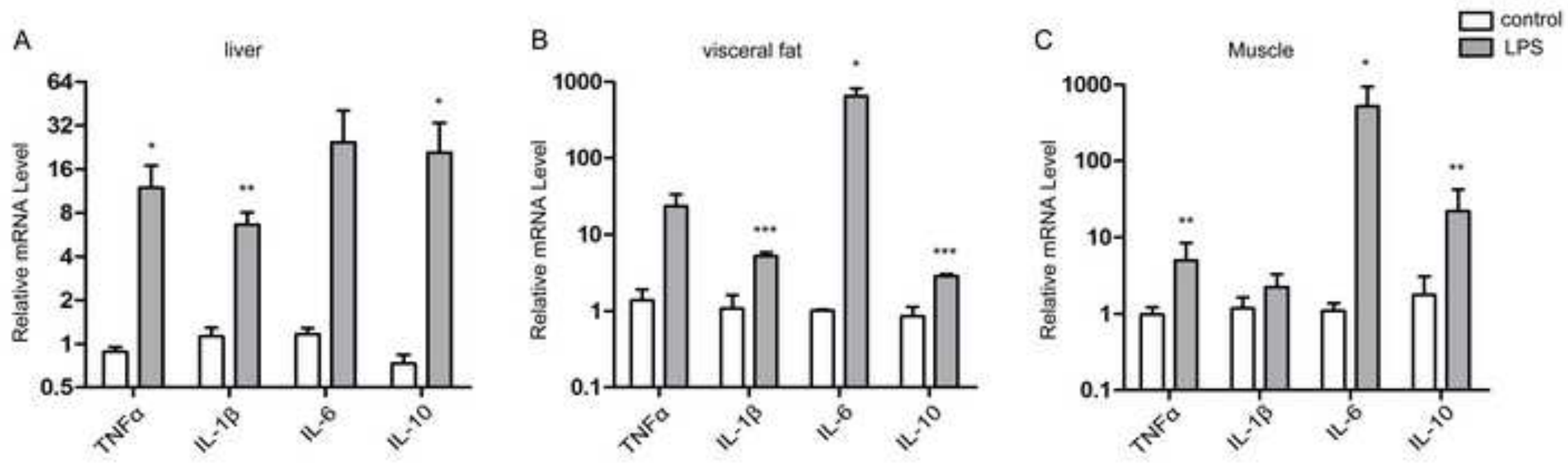


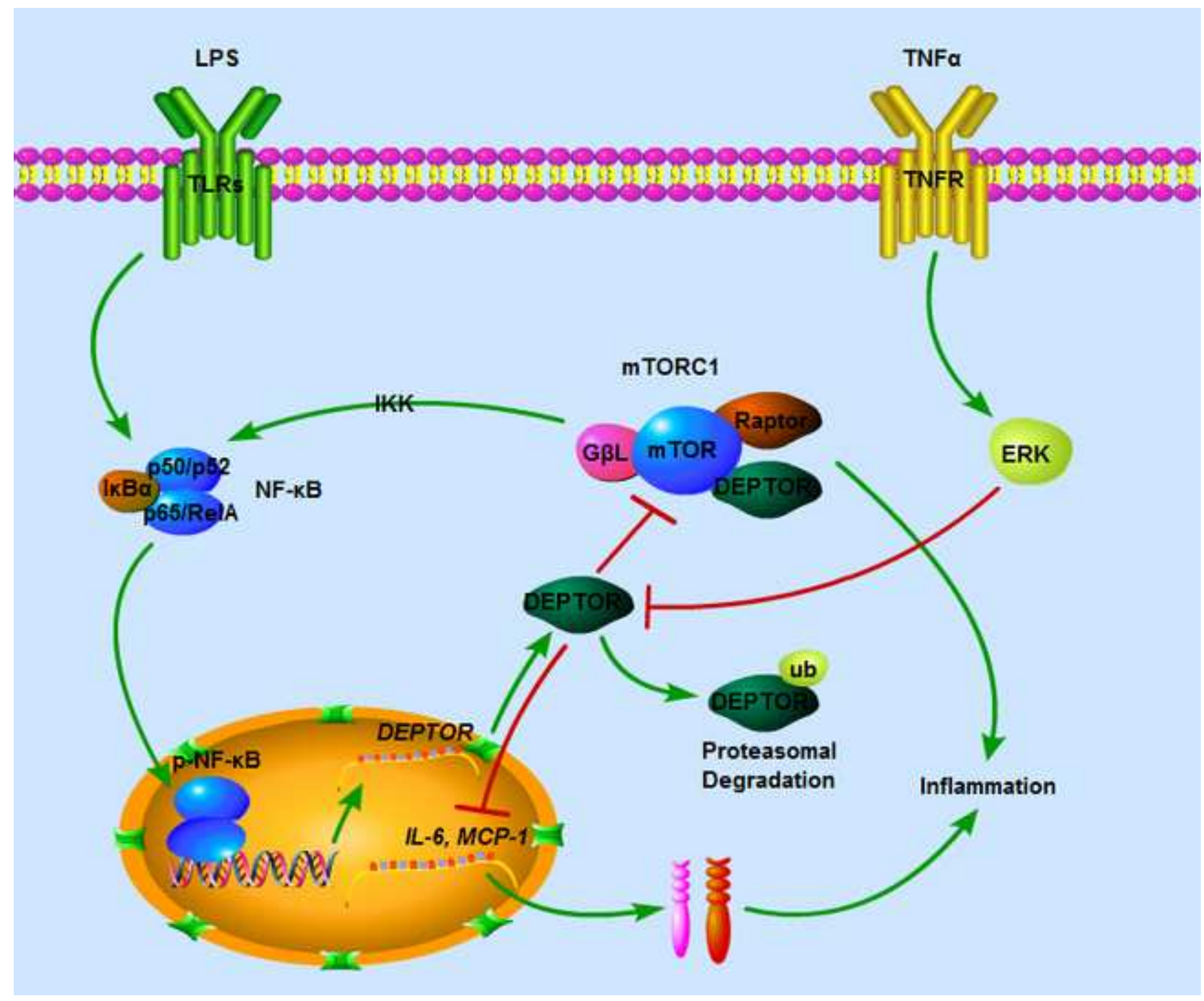

